\title{
Extracts From Red Eggplant: Impact of Ohmic Heating and Different Extraction Solvents on the Chemical Profile and Bioactivity
}

\author{
Pedro Ferreira-Santos ${ }^{1 *}$, Anna Barbara Duca ${ }^{2}$, Zlatina Genisheva ${ }^{1}$, Beatriz Nunes Silva ${ }^{1,3}$, \\ Filomena De Biasio ${ }^{4}$, Cláudia Botelho ${ }^{1}$, Cristina M. R. Rocha ${ }^{1}$, Domenico Gorgoglione ${ }^{2}$ \\ and José A. Teixeira ${ }^{1 *}$ \\ ${ }^{1}$ Centre of Biological Engineering, University of Minho, Braga, Portugal, ${ }^{2}$ EVRA S.r.l., Lauria, Italy, ${ }^{3}$ Centro de Investigação \\ de Montanha, Instituto Politécnico de Bragança, Bragança, Portugal, ${ }^{4}$ Osun Solutions S.r.l., Lauria, Italy
}

Eggplants contain a multitude of biocompounds with nutritional and/or biological activities. The objective of this work was to study the nutritional, chemical and bioactive value of red eggplant from Rotonda, Italy. Ohmic heating $(\mathrm{OH})$ was compared to conventional heating, as different solvents were used (water, ethanol 30, 50, and 90\% and methanol) for biocompounds extraction. Extracts were evaluated for their total phenolic compounds, antioxidant and antibacterial activities, and its toxicity was assessed in cells, L929 and Caco-2. The nutritional characterization of Rotonda's eggplant demonstrated that it is rich in carbohydrates (65\%), fiber (12.5\%), proteins (13\%), lipids (7.6\%) and minerals. Potassium is the mineral with the highest concentration in the red eggplant (27.24 mg/g). Phenolic composition of the obtained extracts was dependent on the extraction method, as well as on the solvent. The use of $\mathrm{OH}$ method increased the extraction of biocompounds, especially when using $50 \%$ of ethanol as solvent. The main phenolic compounds found in the extracts of this eggplant variety were ellagic acid, p-coumaricic acid, epicatechin, narginin, taxifolin and kaempferol. Antioxidant activity was positively correlated with the total amounts of phenolics. Red Eggplant extracts showed activity against Gram-negative bacteria (E. coli and S. enterica), however, they did not demonstrate activity against Gram-positive bacteria. The extracts obtained did not show cytotoxic effects in fibroblast and colorectal studied cells. Ohmic heating is a sustainable technology that increases the extraction yield of biocompounds, with reduced energy consumption and the resulting extracts show low toxicity and high biological activity.

\footnotetext{
Keywords: red eggplant, nutritional value, ohmic heating, phenolic compounds, antioxidant activity, antibacterial activity, cytotoxicity
}

\section{INTRODUCTION}

Eggplant (also known as brinjal, aubergine, melanzana, or berenjena) together with potato, tomato and pepper belong to the family Solanaceae (Doganlar et al., 2002). Nowadays, eggplant is an economically important vegetable crop with a large number of fruit varieties ranging in size, shape, and color. The taxonomy of eggplants is complicated and at the same time still unclear 


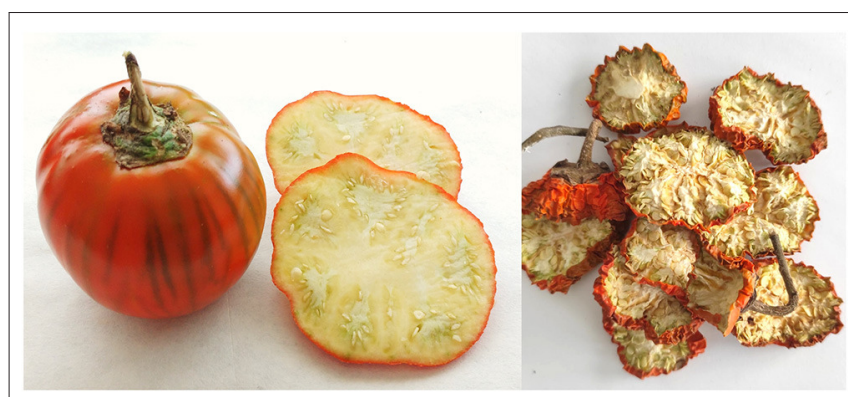

FIGURE 1 | Solanum aethiopicum L. cv. red eggplant from Rotonda, Italy.

(Haliński et al., 2017). The main cultivars are the Brinjal eggplant (Solanum melongena L.), the Gboma eggplant (Solanum macrocarpon L.) and the Scarlet eggplant (Solanum aethiopicum L.). This vegetable is native from India. China and Japan appear as secondary centers of origin and progressively its cultivation spread to the Mediterranean, Africa, Europe and America and is cultivated worldwide today.

Italy is the main European producer of eggplant, 300,620 tons in 2019 [Food and Agriculture Organization of the United Nations (FAO). FAOSTAT]. Populations of scarlet eggplants found in a specific area of Potenza (Basilicata, South of Italy) including villages of Rotonda, Viggianello, Castelluccio Superiore and Castelluccio Inferiore are known locally as "melanzana rossa di Rotonda" (Sunceri et al., 2010). The Red Eggplant (Figure 1) cultivated in this area has recently gained the Protected Designation of Origin (PDO) and is widely used for human consumption as a fresh, dehydrated vegetable or as jams (Parisi et al., 2018).

In the recent years eggplants have gained the attention of consumers and scientists as a source of molecules with promising biological and nutritional value (Gürbüz et al., 2018; Mauro et al., 2020). The reported chemical composition suggests that eggplants are characterized by different biological properties, such as antioxidant, anti-inflammatory, cardioprotective, anti-obesity, and anti-diabetic, anti-carcinogenic and antibacterial, probably due to its phenolic composition (Gürbüz et al., 2018).

Parisi et al. (2018) studied Rotonda's red eggplant extract for the first time in 2018. The extract was considered a possible nutraceutical supplement due to its antioxidant, antihypertensive, hypoglycemic and hypolipidemic properties (Parisi et al., 2018). Their results showed that the consumption of the eggplant extracts can be beneficial in combination with traditional therapies in the control of different metabolic disorders such as hyperglycemic condition, hypertensive state, lipid accumulation and to ameliorate mineral deficiency.

Ohmic heating $(\mathrm{OH})$ is a green and emerging electrotechnology with great potential to promote the extraction of biocompounds (like essential oils, pectin, pigments, and phenolic compounds) due to its electropermeabilization effect on the cell membranes, improving the release of compounds (Sastry, 2008; Gavahian et al., 2015; Loypimai et al., 2015;
Pereira et al., 2016; Hashemi et al., 2017; Saberian et al., 2017; Ferreira-Santos et al., 2019; Jesus et al., 2020). Moreover, $\mathrm{OH}$ shows to improve the process efficiency, reduces the use of solvents and energy costs, maintaining the quality and functionality of the obtained products (Sastry, 2008; Rocha et al., 2018). So far, there are no studies using $\mathrm{OH}$ for the extraction of biocompounds from eggplant. But, on the other hand, $\mathrm{OH}$ has proved to be particularly effective in extracting phenolic compounds (e.g., pine bark and microalgae), with important gains in terms of extraction efficiency and selectivity for phenolic compounds (Ferreira-Santos et al., 2019, 2021b).

Little is known about the chemical/proximate composition of Rotonda's red eggplant as well as on the chemical characterization of their bioactive ingredients. Thus, the objectives of this work were to determine the nutritional value, and chemically characterize the extracts obtained under the application of $\mathrm{OH}$ technology using different solvents in the extraction of bioactive compounds from Solanum aethiopicum L. cv. Red Eggplant from Rotonda, Italy. The chemical characterization of extracts, specifically the individual phenolic compounds, their cytotoxicity and in vitro biological activity (antioxidant and antibacterial) were evaluated.

\section{MATERIALS AND METHODS}

\section{Red Eggplant Preparation and Characterization}

Red eggplant was collected in Rotonda, Basilicata, South of Italy in August 2018. Firstly, the eggplant was washed with water and dried at $45^{\circ} \mathrm{C}$ for $34 \mathrm{~h}$ and subsequently milled in a cutting mill (Retsch SM 2000) to a granulometry of $0.45-0.7 \mathrm{~mm}$ for general chemical composition and $0.7-2 \mathrm{~mm}$ for extraction process.

Chemical/proximal composition of dried Red eggplant was determined in terms of proteins, fiber, lipids, extractives, ash, moisture, total carbohydrates and minerals. The total proteins content was estimated by quantification of total nitrogen after sample acid digestion using a Kjeldahl digestor (Tecator, FOSS, Denmark), applying the nitrogen conversion factor $(N$ $\times$ 6.25) (Graziani et al., 2013). Lipid content was evaluated through extraction with an automatic Soxhlet extraction system (Soxtec $^{\text {TM }}$ 8000, FOSS, Denmark) using petroleum ether as solvent at $80^{\circ} \mathrm{C}$ for $12 \mathrm{~h}$ (Tibbetts et al., 2015). Total dietary fiber content was determined by the AOAC 985.29 gravimetric method using a Megazyme ${ }^{\circledR}$ assay kit. Total extractives were determined in accordance to National Renewable Energy Laboratory (NREL) procedure (Sluiter et al., 2008). For the exhaustive extraction $2 \mathrm{~g}$ of eggplant were used in $100 \mathrm{~mL}$ of ethanol $96 \%(\mathrm{v} / \mathrm{v})$ during $21 \mathrm{~h}$ at $100^{\circ} \mathrm{C}$ in the Soxhlet system. Ash content was determined gravimetrically through total incineration of eggplant biomass in a muffle furnace at $575^{\circ} \mathrm{C}$ for $24 \mathrm{~h}$. Moisture was determined gravimetrically using a moisture analyzer (MAC 50/1/NH, RADWAG, Poland). Mineral content was determined using inductively coupled plasma atomic emission spectrometry (ICP-AES), after Red eggplant digestion with $\mathrm{HNO}_{3}(65 \%)$ and $\mathrm{H}_{2} \mathrm{O}_{2}(35 \%)$ using a microwave apparatus 
(Batista et al., 2013). Total carbohydrates content was estimated by difference using Equation (1) (Lu et al., 2010). All experiments were performed in triplicate.

$$
\begin{aligned}
\text { Carbohydrates }(\%) & =100-(\text { moisture }+ \text { ash }+ \text { crude protein } \\
& + \text { crude lipid })
\end{aligned}
$$

The Red eggplant energy value was calculated according to the Equation (2).

$$
\begin{aligned}
\text { Energy }(\mathrm{kcal}) & =4 \times(\mathrm{g} \text { protein }+\mathrm{g} \text { carbohydrate }) \\
& +9 \times(\mathrm{g} \text { fat })
\end{aligned}
$$

\section{Extraction Conditions and Extracts Preparation}

For the extractions, $2 \mathrm{~g}$ of dried Red eggplant were mixed with $20 \mathrm{~mL}$ of solvent. Different solvents were used, which included methanol, ethanol and water. Ethanol was used in mixtures with water to obtain different concentrations $(30,50,70$, and $90 \% \mathrm{v} / \mathrm{v})$, methanol was used at $99 \%(\mathrm{v} / \mathrm{v})$ and water was distilled. The extractions were carried out in a reactor vessel at $80^{\circ} \mathrm{C}$ for $25 \mathrm{~min}$ with a magnetic stirrer (size of $0.5 \mathrm{~cm}$ ) at $150 \mathrm{rpm}$ to homogenize the solution and improve heat transfer during the heating cycle (conditions chosen from preliminary study, data not shown).

Extractions were performed in a cylindrical glass reactor, double-walled water-jacketed $(3 \mathrm{~mm}$ of internal diameter and $100 \mathrm{~mm}$ height) with two stainless-steel electrodes insulated with polytetrafluoroethylene (distance between electrodes was kept constant, $3.2 \mathrm{~cm}$ ) with overall volume of the reactor $25 \mathrm{~mL}$ (Pereira et al., 2016). The reactor was covered properly with aluminum foil to avoid the direct incidence of light.

For the conventional thermal extraction $(0 \mathrm{~V} / \mathrm{cm})$, a thermostatic circulator water system (F25-ED, Julabo, Seelbach, Germany) was used to get the same heating rates in all types of treatments.

For $\mathrm{OH}$ experiments (at $10 \mathrm{~V} / \mathrm{cm}$ ), the power source worked with a sinusoidal wave at $20 \mathrm{kHz}$ (Agilent $33220 \mathrm{~A}, 1 \mathrm{~Hz}-25 \mathrm{MHz}$ and 1-10 V; Penang, Malaysia). Frequency was set at $20 \mathrm{kHz}$ in order to eliminate the electrochemical effects as electrolysis and electrode oxidation (Pataro et al., 2014).

Temperature was recorded with a stainless-steel type$\mathrm{K}$ thermocouple (temperature precision of $\pm 1^{\circ} \mathrm{C}$; Omega Engineering, Inc., Stamford, CT, USA), located in the geometric center of the reactor. The thermocouple was connected to a data logger (USB-9161, National Instruments Corporation, Austin, TX, USA) and Lab View 7 Express software (National Instruments, NI Data logger) was used to extract the data. A portable oscilloscope (ScopeMeter ${ }^{\circledR}$ 125/S, Fluke, WA, USA) was used to measure electrical frequency, voltage and current intensity during $\mathrm{OH}$ treatments.

Electrical conductivity of $4.5 \pm 0.2 \mathrm{mS} / \mathrm{cm}$ was adjusted in all experiments using $\mathrm{NaCl}$ [measured at room temperature using a conductivity/ TDS/Salinity Meter (HANNA Instruments Inc., edge, HI2003, USA)] to ensure a homogeneous current flow, important for the $\mathrm{OH}$ experiments. Extractions were made in triplicate.
The produced extracts were filtered through $11 \mu \mathrm{m}$ filter paper, under vacuum. The extracts were centrifuged at 6,000 rpm for $6 \mathrm{~min}$ and the supernatant was recovered and stored at $4^{\circ} \mathrm{C}$ until analyses, and some was dried by freeze drying and keep at $4^{\circ} \mathrm{C}$.

\section{Chemical Characterization of Red Eggplant Extracts Total Phenolic Compounds Quantification}

The total phenolic compounds (TPC) content was determined using the Folin-Ciocalteu colorimetric assay, as previously described (Ferreira-Santos et al., 2019). Briefly, Folin-Ciocalteu method is based on an oxidation-reduction reaction between the Folin reagent and with the reducing phenolic compounds. For the analysis, $5 \mu \mathrm{L}$ of each sample were mixed with 60 $\mu \mathrm{L}$ of $\mathrm{Na}_{2} \mathrm{CO}_{3}(75 \mathrm{~g} / \mathrm{L}), 15 \mu \mathrm{L}$ of Folin-Ciocalteu reagent and $200 \mu \mathrm{L}$ of ultra-pure water and the mixture was kept at $60^{\circ} \mathrm{C}$ for $5 \mathrm{~min}$. The absorbance was measured at $700 \mathrm{~nm}$ using a UV/Vis spectrophotometer (Synergy HT, BioTek Instruments, Inc., USA). The phenolic compounds content was calculated as gallic acid equivalents (GAE) using a calibration curve prepared with standard gallic acid $\left(2,000-100 \mathrm{mg} / \mathrm{L}, R^{2}=0.99\right)$. The results were expressed as milligrams of GAE per gram of dry eggplant material (mg GAE/g dw).

\section{Carbohydrates Quantification}

Total carbohydrates (TC) content was measured using the phenol-sulfuric acid method (Masuko et al., 2005). For this, 50 $\mu \mathrm{L}$ of sample were mixed with $150 \mu \mathrm{L}$ of sulfuric acid [96$98 \%(\mathrm{v} / \mathrm{v})]$. Then, $30 \mu \mathrm{L}$ of $5 \%$ phenol reagent were added and the final solution was heated for $5 \mathrm{~min}$ at $90^{\circ} \mathrm{C}$. After cooling at room temperature for $5 \mathrm{~min}$, the absorbance was measured at $490 \mathrm{~nm}$ by a microplate reader (Synergy HT, BioTek Instruments, Inc., USA) (Masuko et al., 2005). The carbohydrates quantification was made using a calibration curve prepared with glucose $\left(600-10 \mathrm{mg} / \mathrm{L}, R^{2}=0.99\right)$ and the results were expressed as milligrams of glucose equivalents (GLUC) per gram of dry eggplant (mg GLUC/g dw).

\section{Protein Quantification}

The protein content was measured by the method of Bradford (1976). For this, $20 \mu \mathrm{L}$ plant extract was mixed with $230 \mu \mathrm{L}$ of Bradford dye reagent. The microplate was placed in the dark for $5 \mathrm{~min}$ and the absorbance was measured at a wavelength of $595 \mathrm{~nm}$ by an UV/Vis spectrophotometer (Synergy HT, BioTek Instruments, Inc., USA). Bovine albumin serum (BSA) was used to perform the standard curve $\left(1,000-33 \mathrm{mg} / \mathrm{L}, R^{2}=0.98\right)$ and the results were expressed as milligrams of BSA equivalents (BSA) per gram of dry eggplant (mg BSAE/g $\mathrm{dw}$ ).

\section{Identification and Quantification of Individual Phenolic Compounds}

Individual phenolic compounds were analyzed by Shimadzu Nexera X2 UHPLC chromatograph equipped with a Diode Array Detector (DAD) (Shimadzu, SPD-M20A, Kyoto, Japan) using a previously validated method, as described by FerreiraSantos et al. (2021a). Separation was performed on a reversed 
phase Acquity UPLC BEH C18 column $(2.1 \times 100 \mathrm{~mm}, 1.7 \mu \mathrm{m}$ particle size; from Waters) and a precolumn of the same material at $40^{\circ} \mathrm{C}$. The flow rate was $0.4 \mathrm{~mL} / \mathrm{min}$. HPLC grade solvents water/formic acid $0.1 \%(\mathrm{~A})$ and acetonitrile (B) were used. The elution gradient for solvent $\mathrm{B}$ was as follows: from 0 to $5.5 \mathrm{~min}$ eluent $\mathrm{B}$ at $5 \%$, from 5.5 to $17 \mathrm{~min}$ linearly increasing from 5 to $60 \%$, from 17 to 18.5 min linearly increasing from 60 to $100 \%$; last, the column is equilibrated at $5 \%$ from 18.5 to $30 \mathrm{~min}$. Phenolic compounds were identified by comparing their UV spectra and retention times with those of corresponding standards. Quantification was carried out using calibration curves for each pure phenolic compound standard using concentrations between 250 and $2.5 \mathrm{mg} / \mathrm{L}$, and the limit of detection (LOD) and limit of quantification (LOQ) were calculated as previously reported by Busaranon et al. (2006). In all cases, the coefficient of linear correlation was $R^{2}>0.99$ (Supplementary Table S1). Compounds were quantified and identified at different wavelengths $(250-370 \mathrm{~nm})$. All analyses were made in triplicate.

\section{Bioactivities of Red Eggplant Extracts Antioxidant Activity}

The antioxidant activity was measured using DPPH, ABTS, and FRAP methods, to evaluate distinct mechanisms of action of the extracts.

The free radical scavenging (DPPH) and the radical cation decolorization (ABTS) assays were conducted as described by Ferreira-Santos et al. (2019). Calibration curves were prepared with a standard solution of 6-hydroxy-2,5,7,8tetramethylchroman-2-carboxylic acid (Trolox) (250-15 $\mu \mathrm{M}, R^{2}$ $=0.998$, for DPPH; and 800-31.25 $\mu \mathrm{M}, R^{2}=0.996$, for ABTS) and a corresponding control was used for each solvent. The radical scavenging activity for DPPH and ABTS methods (\% inhibition) was calculated as Equation (3).

$$
\% \text { Inhibition }=\frac{A c-A s}{A c} \times 100
$$

Where, As is the sample absorbance and Ac the control sample absorbance. The results were expressed as micromoles of Trolox equivalent (TE) per gram of dry eggplant ( $\left.\mu \mathrm{mol} \mathrm{TE} / \mathrm{g}_{\mathrm{dw}}\right)$.

The ferric reducing antioxidant power (FRAP) assay was performed as described by Meneses et al. (2013). A calibration curve was prepared using an aqueous solution of ferrous sulfate $\left(800-100 \mu \mathrm{M}, R^{2}=0.98\right)$. FRAP values are expressed as micromoles of ferrous equivalent per $g$ of dry eggplant ( $\left.\mu \mathrm{mol} \mathrm{Fe} \mathrm{F}^{2+} / \mathrm{g} \mathrm{dw}_{\mathrm{w}}\right)$.

\section{Antibacterial Activity}

From all the extracts produced, the extract obtained by $\mathrm{OH}$ using ethanol $50 \%(\mathrm{v} / \mathrm{v})$ was selected for presenting distinctive results in terms of chemical profile (specifically, phenolic compounds content) and antioxidant activity. Two Gram-negative bacteria Escherichia coli (ATCC 25922) and Salmonella enterica serovar Enteritidis (ATCC 25928), and two Gram-positive bacteria: Listeria monocytogenes (WDCM 00019) and Staphylococcus aureus (ATCC 6538) obtained from the Centre of Biological Engineering, University of Minho
(Braga, Portugal) stock collection, were used for the evaluation of the antibacterial activity of the extracts. Bacteria strains were replicated on blood agar and incubated at $37^{\circ} \mathrm{C}$ for $24 \mathrm{~h}$ to ensure that bacterial cells were in the exponential growth phase. Single colonies were inoculated using sterile water and the bacterial suspensions were adjusted to a concentration of $\sim 1.5 \times 10^{8} \mathrm{CFU} / \mathrm{mL}$ (0.5 McFarland). The minimal inhibitory concentrations (MIC) were determined by the broth microdilution method according to the Clinical and Laboratory Standards Institute (CLSI) recommendations (CLSI, 2012), with some minor modifications. The minimal bactericidal concentrations (MBC) were also determined by subcultivation of $10 \mu \mathrm{L}$ of the microplate wells containing extracts at 20 and $10 \mathrm{mg} / \mathrm{mL}$ into blood agar plates. The lowest concentration that showed no growth after this subculturing was regarded as the MBC. The results were expressed in milligrams per milliliter of the resuspended lyophilized extracts $(\mathrm{mg} / \mathrm{mL})$. The MIC experiments were performed four times and the MBC tests were carried in duplicate.

\section{Cytotoxicity}

In vitro cytotoxicity of the Red eggplant extract [obtained by Ohmic heating using ethanol 50\% (v/v)] was assessed in mouse fibroblast (L929, ATCC ${ }^{\circledR}$ CCL-1) and human colorectal cell lines (Caco-2, ATCC ${ }^{\circledR}$ HTB- $37^{\mathrm{TM}}$ ). The metabolic activity of each cell line was evaluated by the resazurin reduction assay (Helm et al., 2017). Cells were grown Dulbecco's Modified Eagle Medium (DMEM) supplemented with $10 \%$ fetal bovine serum (FBS) and $1 \%$ penicillin/streptomycin, at $37^{\circ} \mathrm{C}$ in a humidified atmosphere with $5 \% \mathrm{CO}_{2}$. When the cell culture reached $70-80 \%$ of confluence, the cells were trypsinized and seeded in a 96-well plate at a density of $1 \times 10^{5}$ cells per well. The different cell lines were incubated with supplemented DMEM and extract in a concentration ranging from 75 to $1,000 \mu \mathrm{g} / \mathrm{mL}$ for $24 \mathrm{~h}$. After incubation, cell viability was measured using the resazurin assay (7-Hydroxy-3H-phenoxazin-3-one-10-oxide sodium salt). The supernatant was replaced by $200 \mu \mathrm{L}$ culture media containing resazurin $(0.5 \mathrm{mM}$ in $\mathrm{PBS})$. After $2 \mathrm{~h}$ of incubation at $37^{\circ} \mathrm{C}$, $150 \mu \mathrm{L}$ of the supernatant were transferred to a new 96well microplate and the pink fluorescent resultant product (resorufin) was detected at $560 \mathrm{~nm}(\lambda \mathrm{ex})$ and $590 \mathrm{~nm}(\lambda \mathrm{em})$ using a microplate reader (Cytation 3, BioTek Instruments, Inc., Winooski, VT, USA). The \% of cell viability was calculated correcting blank values (cell-free medium) and related to untreated controls (0.5\% DMSO).

\section{RESULTS AND DISCUSSION}

\section{Proximate Composition of Red Eggplant}

The first step in this work was the chemical and nutritional evaluation of the PDO Rotonda's red eggplant. The results are displayed in Table $\mathbf{1 .}$

The results show that carbohydrates are the major fraction of the total eggplant composition, accounting for $65.3 \%$ of its weight. The total extractives (including some soluble carbohydrates, protein and ash) represent $46.7 \%$ of total red eggplant composition. 
TABLE 1 | Chemical, nutritional, and elementary (minerals) composition of dried Red eggplant.

\begin{tabular}{|c|c|c|c|}
\hline \multicolumn{2}{|c|}{$\begin{array}{l}\text { Proximate composition } \\
(\mathrm{g} / 100 \mathrm{~g} \pm \mathrm{SD})\end{array}$} & \multicolumn{2}{|c|}{$\begin{array}{l}\text { Elemental composition } \\
\qquad(\mathrm{mg} / \mathrm{g} \pm \mathrm{SD})\end{array}$} \\
\hline Total carbohydrates & $65.32^{\star}$ & Potassium & $27.24 \pm 0.44$ \\
\hline Total extractives & $46.73 \pm 0.19$ & Calcium & $5.23 \pm 0.06$ \\
\hline Protein & $12.97 \pm 0.09$ & Magnesium & $5.07 \pm 0.02$ \\
\hline Fiber & $12.45 \pm 0.70$ & Aluminum & $0.90 \pm 0.09$ \\
\hline Lipids & $7.64 \pm 0.10$ & Iron & $0.23 \pm 0.00$ \\
\hline Ash & $4.60 \pm 0.04$ & Sodium & $0.20 \pm 0.00$ \\
\hline Moisture & $9.47 \pm 0.03$ & Zinc & $0.09 \pm 0.00$ \\
\hline \multirow[t]{8}{*}{ Energy (kcal/100 g) } & 382 & Manganese & $0.07 \pm 0.00$ \\
\hline & & Copper & $<\mathrm{DL}$ \\
\hline & & Cadmium & $<\mathrm{DL}$ \\
\hline & & Gallium & $<\mathrm{DL}$ \\
\hline & & Barium & $<\mathrm{DL}$ \\
\hline & & Nickel & ND \\
\hline & & Cobalt & ND \\
\hline & & Lead & ND \\
\hline
\end{tabular}

$<D L$, below detection limit; ND, not determined; ${ }^{\star} T o t a l$ carbohydrates content was estimated by difference.

It is known that the eggplant fruit contains a high percentage of water and a low protein content (Raigón et al., 2008). The protein content of Rotonda's red was $12.97 \mathrm{~g}$ per $100 \mathrm{~g}$ of dry weight. This content in protein is comparable to other Scarlet eggplant species that showed an average value of $11.7 \mathrm{~g}$ per $100 \mathrm{~g}$ of dry weight (San José et al., 2016). The moisture in the present case was lower than $10 \%(9.47 \%)$, which is due to the drying process applied to the raw material before use.

Other constituents, such as crude fiber, lipid fraction (fat) and ash content represent $12.5,7.6$, and $4.6 \%$ of total composition, respectively. These data are in accordance with previous studies of tropical Solanum species carried out by Nwanna et al. (2019).

There is a lack of studies on the mineral composition variation among different varieties of eggplant (Raigón et al., 2008). Moreover, as far as we know this is the first study of the general elementary composition of Rotonda's red eggplant. It is known that environmental conditions can influence the composition of eggplant, including the dry matter content and mineral composition (Raigón et al., 2008). Fifteen minerals were identified in this eggplant. Some of the minerals were not quantified, as their amount was below the detection limit (Copper - Cu, Cadmium - Cd, Gallium - Ga, Barium - Ba, Nickel $\mathrm{Ni}$, Cobalt - Co and Lead - Pb). According to the elementary composition, the mineral with the highest concentration in the eggplant in study is potassium $(\mathrm{K})(27.24 \mathrm{mg} / \mathrm{g})$. This is in accordance with previous studies by Raigón et al. (2008). Authors demonstrated that in the 31 varieties of eggplant (S. melongena) $\mathrm{K}$ was the mineral with the highest concentration with an average value of $200 \mathrm{mg}$ per $100 \mathrm{~g}$ of fresh weight. The second and third most abundant minerals detected in Rotonda's red eggplant were calcium - Ca and magnesium - Mg with concentrations of 5.23 and $5.07 \mathrm{mg} / \mathrm{g}$, respectively. As described in the literature $\mathrm{Ca}$
TABLE 2 | Extraction yields (\%) from Red eggplant obtained by ohmic heating and conventional heating extraction with different solvents: water, ethanol (EtOH) and methanol $(\mathrm{MtOH})$.

\begin{tabular}{lcc}
\hline Extraction & Ohmic heating & Conventional heating \\
\hline Water & $36.6 \pm 0.7$ & $37.1 \pm 1.9$ \\
$\mathrm{EtOH} \mathrm{30 \%}$ & $44.6 \pm 2.1$ & $43.0 \pm 0.3$ \\
$\mathrm{EtOH} \mathrm{50 \%}$ & $61.1 \pm 0.7^{*}$ & $48.1 \pm 1.3$ \\
$\mathrm{EtOH} \mathrm{70 \%}$ & $64.9 \pm 1.3^{*}$ & $49.7 \pm 0.8$ \\
$\mathrm{EtOH} \mathrm{90 \%}$ & $46.4 \pm 0.3^{*}$ & $38.7 \pm 1.0$ \\
$\mathrm{MtOH} 99 \%$ & $55.5 \pm 0.1^{*}$ & $42.6 \pm 0.3$ \\
\hline
\end{tabular}

Values are expressed as mean (\%) $\pm S D$ of three experiments. *Show significant differences $(p<0.05)$ between extraction technologies for the same solvent.

and phosphorous $(\mathrm{P})$ were the second and third most abundant minerals present in $S$. melongena varieties with an average value of $0.015 \mathrm{mg}$ per $\mathrm{g}$ of fresh weight and $0.025 \mathrm{mg}$ per $\mathrm{g}$ of fresh weight, respectively (Raigón et al., 2008). Aluminum (Al), sodium $(\mathrm{Na})$ and iron $(\mathrm{Fe})$ were detect with concentrations of 0.9 , 0.20 , and $0.23 \mathrm{mg}$ per $\mathrm{g}$ of dry weight, respectively. The minerals with the lowest values were Zinc ( $\mathrm{Zn}$ ) with $0.09 \mathrm{mg}$ per $\mathrm{g}$ of dry weight and Manganese (Mn) $0.07 \mathrm{mg} / \mathrm{g}$.

\section{Influence of Chemical Characteristics on Red Eggplant Extracts Differentiation}

To obtain a detailed characterization of this eggplant variety, different solvents [water, ethanol 30, 50, 70, 90\% and methanol 99\% (v/v)] and methods of extraction (Conventional heating and $\mathrm{OH}$ ) were used.

Different solvents were used with the intent of the elution of different chemic compounds based on their polarity. Moreover, methanol is one of the most used solvents for extraction of bioactive compounds, like phenolic compounds, from several fruits and plants by-products, allowing direct comparisons with other similar plants.

The extracts were analyzed for TPC, carbohydrates and proteins. The $\mathrm{pH}$ of the extracts was measured and the values were between 5.13 and 5.84, as expected. Previously, San José described a similar extract with $\sim 5.70 \mathrm{pH}$ units (San José et al., 2016).

Extraction yields are different depending on the solvent and the extraction technique used (see Table 2). For conventional extraction the yields are $37.1 \%$ for water, $43.0 \%$ for $\mathrm{EtOH} 30 \%$, $48.1 \%$ for $\mathrm{EtOH} 50 \%, 49.7 \%$ for $\mathrm{EtOH} 70 \%$, 38.7\% for $\mathrm{EtOH} 90 \%$ and $42.6 \%$ for $\mathrm{MeOH} 99 \%$. However, for $\mathrm{OH}$-assisted extraction the yield values are significantly higher, except using water and ethanol $30 \%$ as solvent which have similar extraction yield to conventional extraction (36.6\% for water, $44.6 \%$ for $\mathrm{EtOH} 30 \%$, 61.1\% for $\mathrm{EtOH} 50 \%$, 64.9\% for $\mathrm{EtOH} 70 \%$, 46.4\% for $\mathrm{EtOH} 90 \%$ and $55.5 \%$ for $\mathrm{MeOH} 99 \%$ ).

Eggplant is amongst the top ten vegetables in terms of oxygen radical absorbance capacity, due to its phenolic constituents (Singh et al., 2009). Phenols are compounds with numerous biological properties as it is widely described (Ferreira-Santos et al., 2020b). In Figure 2A it can be observed that the quantity of the extracted phenolic compounds increased with the increasing 
A

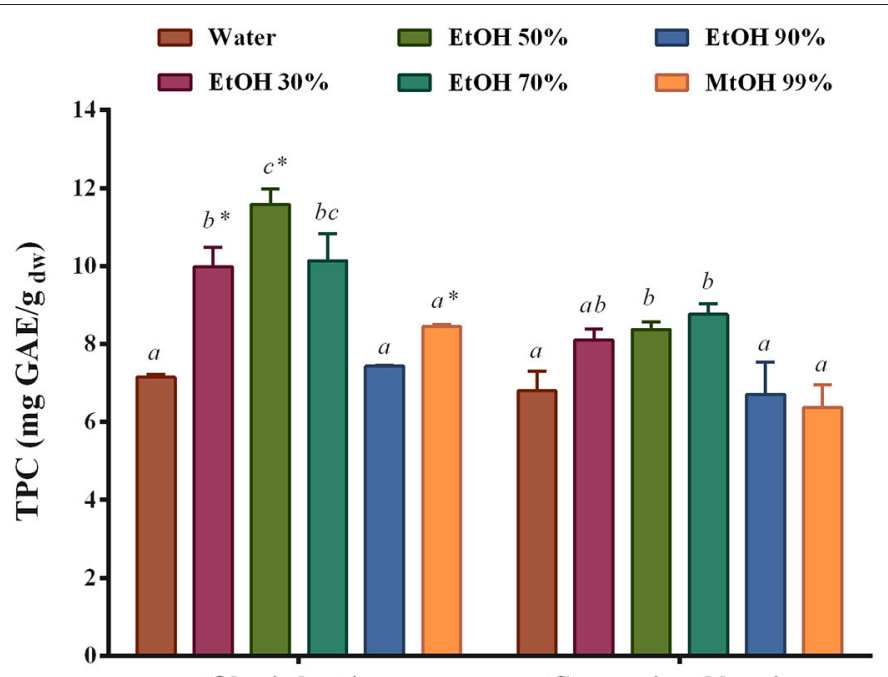

Ohmic heating

Conventional heating

B



C

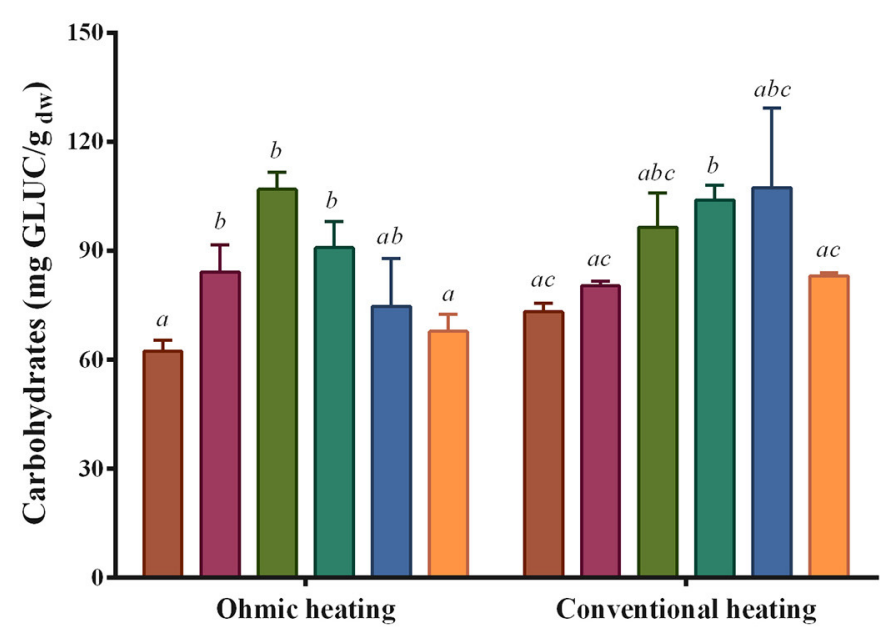

FIGURE 2 | Total phenolic (TPC) (A), protein (B), and carbohydrate (C) extraction yields of Red eggplant extracts. Influence of solvents using conventional heating and $\mathrm{OH}$-assisted extraction methods. Values are expressed as mean $\pm \mathrm{SD}$. Different letters show significant differences $(p<0.05)$ between extraction solvents for the same extraction technologies. *Show significant differences $(p<0.05)$ between extraction technologies for the same solvent. 
concentration of ethanol (up to 50\%), and decreased when using ethanol $90 \%$ and pure methanol. The highest value of TPC was achieved for the extract obtained with $50 \%$ ethanol with a value of $9.9 \mathrm{mg} \mathrm{GAE} / \mathrm{g}$. This value is very low in comparison to the one described by Parisi et al. (2018), who obtained a value of $77 \mathrm{mg}$ CAE/g for Rotonda's red eggplant extracts. This difference can be explained due to the different methods of extraction used (ultrasound, 5\% of hydrochloric acid in distilled water for $1 \mathrm{~h}$ ) and equivalents of quantification. However, the presented results are comparable with the results published by Mauro et al. (2020) for the $S$. melongena cultivar, using similar extraction conditions (1:10 solid/liquid ratio and $70 \%$ methanol), obtained a TPC with an of average of $8.5 \mathrm{mg} / \mathrm{g}$ dry weight.

In regards to the extract's protein content it is clear from Figure 2B that the highest amount of protein was obtained when using $70 \%$ of ethanol, $3.8 \mathrm{mg}$ BSA/g dry eggplant. This result is in agreement with the literature, which reports the low protein content of 31 varieties of eggplant $S$. melongena (Raigón et al., 2008), with values ranging from 4.1 to $6.8 \mathrm{mg} / \mathrm{g}$. The difference observed in the protein content is perhaps related to the methodology used for protein quantification in this work, which was different from the one reported in the previous study. However, San José et al. (2016) found that scarlet S. aethiopicum eggplant has significantly higher average values of protein in comparison to S. melongena eggplant.

The highest values of carbohydrates were found in the extracts with 50 and $70 \%$ of ethanol with values of 101.7 and $97.4 \mathrm{mg}$ GLUC/g dry eggplant, respectively (Figure 2C). Zaro et al. (2014) demonstrated that purple eggplant have higher content of soluble carbohydrates than white eggplant. Moreover, the concentration of carbohydrates is higher in the inner pulp of the fruits. The amount of carbohydrates found in these two varieties of S. melongena (between 26.6 and $41.1 \mathrm{mg}$ GLUC/g dry eggplant) were lower than those obtained for Rotonda's red eggplant (Zaro et al., 2014). However, in another study the amount of total carbohydrates of 35 varieties of eggplants (33 S. melongena and two S. aethiopicum) achieved values between 170 and $440 \mathrm{mg}$ sucrose equivalent (Hanson et al., 2006).

Independently from the solvent used, the $\mathrm{OH}$ treatment resulted in higher amounts of TPC and proteins compared to the conventional heating. On the other hand, the carbohydrates' extracted amount was not influenced by the method of extraction, only by the solvent used.

\section{Individual Phenolic Compounds of Red Eggplant Extracts}

The phenolics' profile of the Red eggplant extracts obtained with different solvents and methods were assessed (Table 3). Phenolic compounds are found in the eggplant pulp and peel, and are significantly influenced by genotype, environment and growth conditions, as well as by cultivation systems (Kacjan Maršic et al., 2014). There are little studies that analyzed the individual phenolic compounds of eggplant species and most of the available results considered only the total phenolic content (Kacjan Maršic et al., 2014).

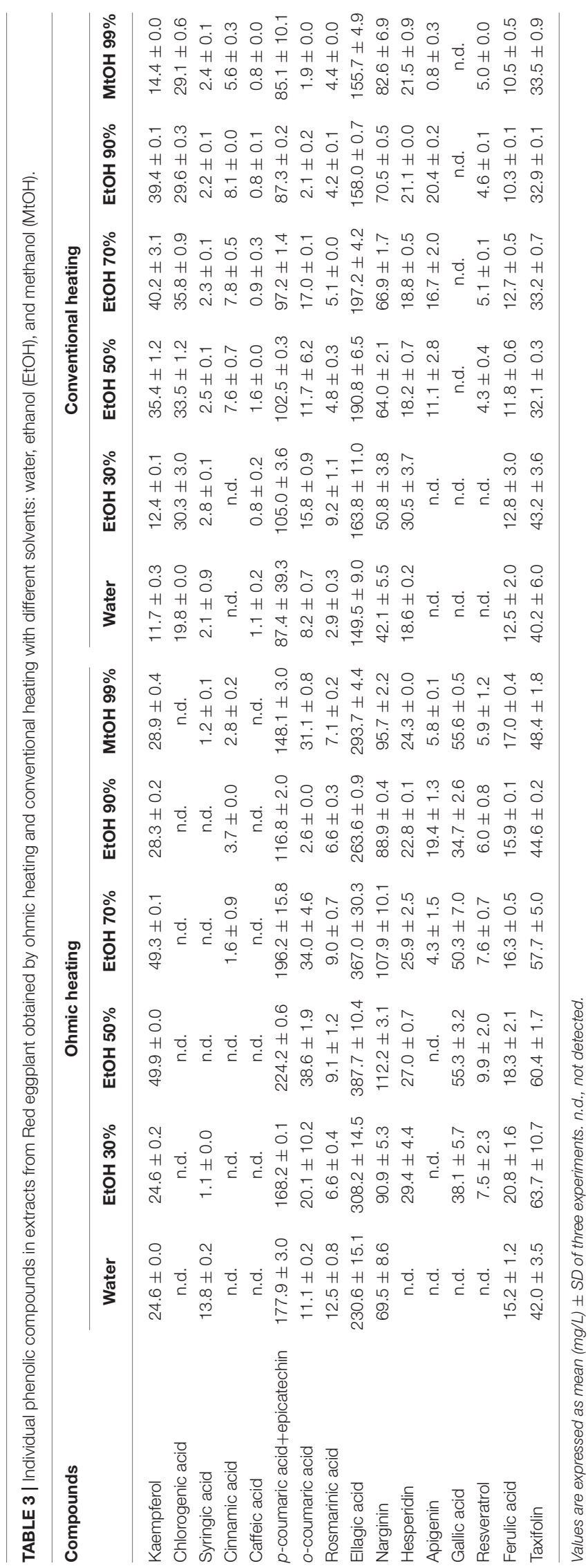



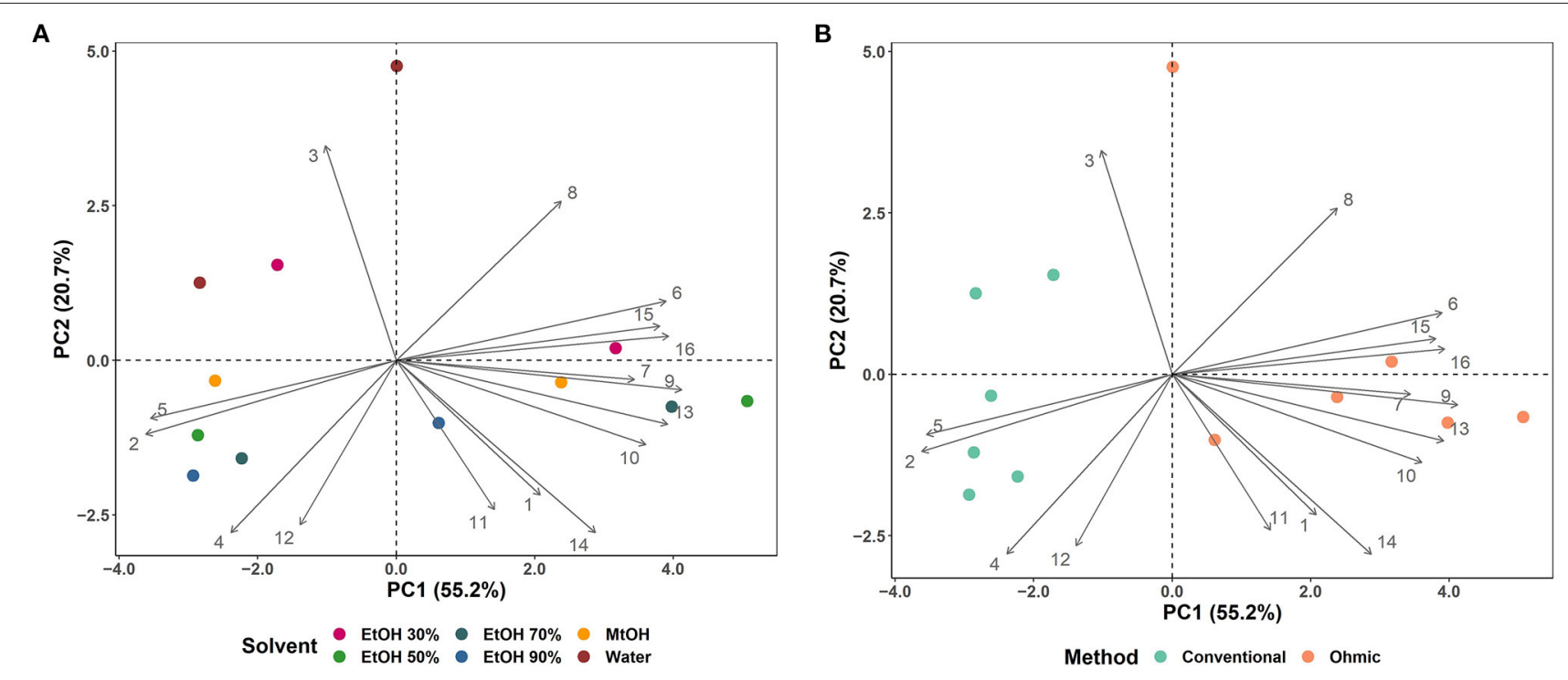

FIGURE 3 | Principal component analysis (PCA) on the obtained extracts from Red eggplant. (A) Phenolic compounds distribution of extracts obtained by different solvents; (B) phenolic compounds distribution of extracts obtained by different extraction methods. 1 - Kaempferol; 2 - Chlorogenic acid; 3 - Syringic acid; 4 Cinnamic acid; 5 - Caffeic acid; 6 - p-coumaric acid + epicatechin; 7 - o-coumaric acid; 8 - Rosmarinic acid; 9 - Ellagic acid; 10 - Naringin; 11 - Hesperidin; 12 Apigenin; 13 - Gallic acid; 14 - Resveratrol; 15 - Ferulic acid; 16 - Taxifolin.

According to Zaro et al. (2014), little is known about antioxidant metabolites like the polyphenols in eggplants. Moreover, as far as we know this is the first study on the individual phenolics present in Rotonda's Red eggplant extracts. In total seventeen phenolic compounds were tentatively identified and quantified in the extracts of this eggplant variety. It was previously stated that tropical Solanum species contains a high level of phenolic acids and flavonoids (Nwanna et al., 2019). Accordingly, the main compounds found in the Rotonda's Red eggplant extracts were ellagic acid (founded at 149.5$387.7 \mathrm{mg} / \mathrm{L})$, p-coumaricic acid+epicatechin (85.1-224.2 mg/L), naringin (42.1-112.2 $\mathrm{mg} / \mathrm{L})$, taxifolin $(63.7$ and $32.1 \mathrm{mg} / \mathrm{L})$, and kaempferol (49.9 and $11.7 \mathrm{mg} / \mathrm{L}$ ). The phenolic compounds like chlorogenic acid, caffeic acid, $p$-coumaric acid, ferulic acid and epicatechin were also found in the pulp of Solanum melongena L. variety (Kacjan Maršic et al., 2014). Hydroxycinnamic acids (chlorogenic acid, caffeic acid, $p$-coumaric acid, ferulic acid) were the highest represented group of phenolics in four eggplant varieties ranging from 25 to $51 \%$ of the total (Kacjan Maršic et al., 2014). This is in accordance with the present study as the group of hydroxycinnamic acids were $\approx 30 \%$ of the total phenolics. The amount of extracted phenolics demonstrated to be dependent on the method of extraction used. $\mathrm{OH}$ allowed the retrieval of higher amounts of phenolics when compared to conventional heating method. Chlorogenic and caffeic acids were only found in extracts obtained with conventional heating. On the contrary gallic acid was only found in extracts made with $\mathrm{OH}$. There are no differences in terms of phenolics between the alcoholic extracts. However, as individual compounds there are some differences between aqueous extract and alcoholic extracts. Naringin and ellagic acid had lower concentrations in aqueous extracts, compared to the alcoholic extracts, while resveratrol and apigenin were not detected in aqueous extracts. This is due to the chemical nature of these phenolics, as they are slightly soluble or even insoluble in water. Regardless the method used the extracts that accounted the highest levels of phenolics were achieved with 50 or $70 \%$ ethanol. When the $\mathrm{OH}$ method was used the extracts accounted for $\approx 1,000 \mathrm{mg} / \mathrm{L}$ of phenolics, while extracts made with conventional heating accounted for $\approx 550 \mathrm{mg} / \mathrm{L}$ (data not shown).

PCA was performed on the phenolic compounds obtained with different solvents (Figure 3A), with ohmic or conventional heating (Figure 3B) to analyze the differences between extracts. The two main components, PC1 and PC2, accounted for $75.9 \%$ of the total variance 55.2 and $20.7 \%$, respectively. The PCA shows the distribution of the extracts according to the type of solvent used (Figure 3A), as well as according to the method of extraction (Figure 3B). Extracts obtained with water and 30\% of ethanol were distinguished from the rest of the extracts and are distributed on the positive load of the variance PC2 (Figure 3A). These extracts are mainly characterized by the phenolics syringic acid, rosmarinic acid, $p$-coumaric acid, epicatechin, ferulic acid and taxifolin. Extracts were also distributed according to the method of extraction used. Extracts made with $\mathrm{OH}$ were mainly on the positive load of PC1 (Figure 3B), while the extraction made with conventional heating were distributed on the negative load of PC1. Most of the phenolic compounds quantified were extracted through the application of electric fields (by $\mathrm{OH}$ ), thus obtaining a higher concentration. The main contribution can be attributed to gallic acid, ellagic acid and $o$-coumaric acid. Conventional extracts were characterized by cinnamic acid, chlorogenic acid, caffeic acid and apigenin. The results of PCA 


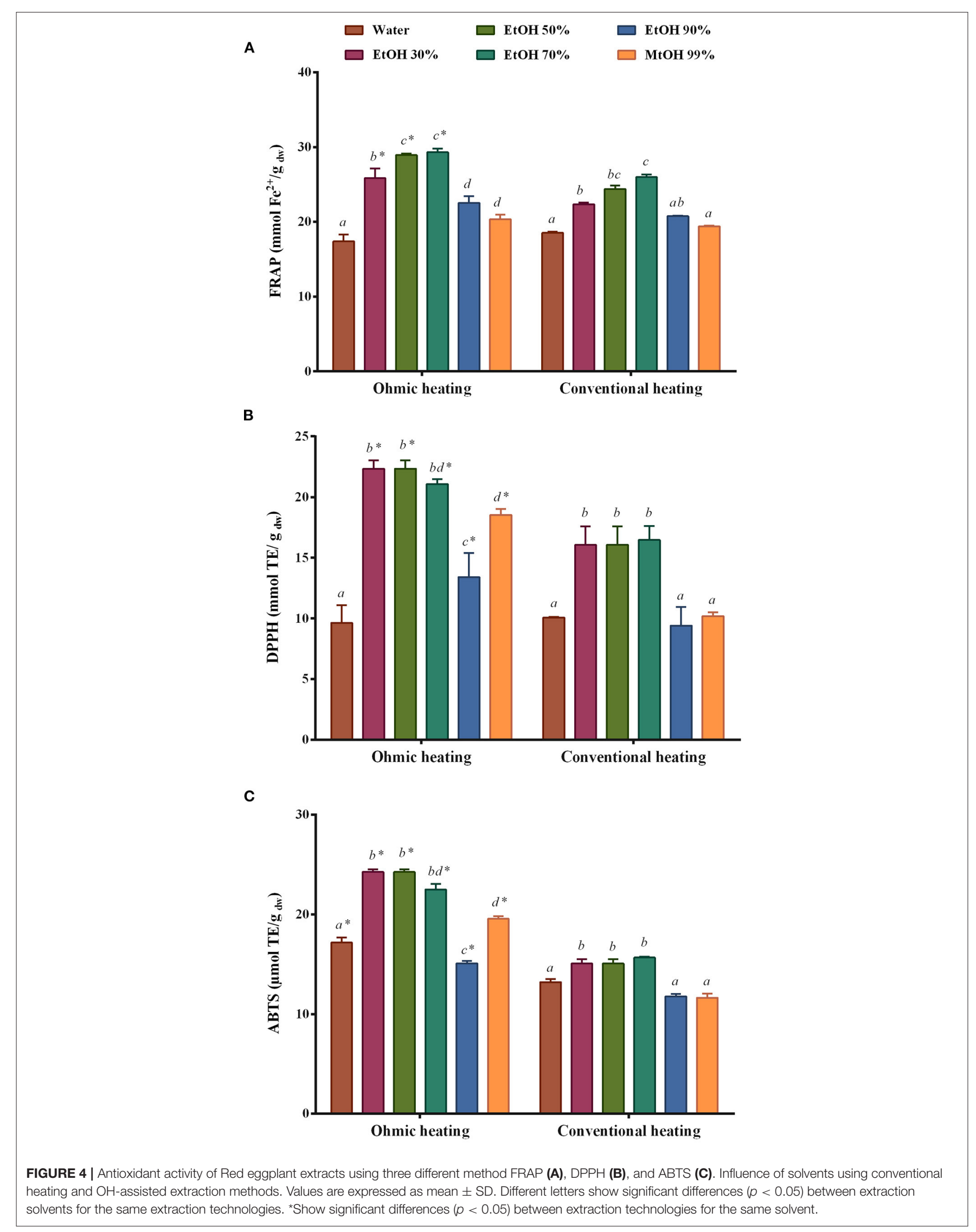


are coherent with the results obtained for the individual phenolic compounds demonstrated on Table 3.

\section{Antioxidant Activity}

Eggplant is one of the vegetables with greatest antioxidant activity. Its antioxidant capacity is ranked in the top ten of 120 different vegetables (Gürbüz et al., 2018). However, it varies according to eggplant variety, fruit shape and size, and also the climate, cultivation method, stage of development of the plant and time of harvesting, etc. (Gürbüz et al., 2018). Moreover, antioxidant capacity is related to skin color and fruit size, as small purple fruit showed higher antioxidant capacity than other eggplant fruit types. In the present study, the antioxidant activity of Rotonda's Red eggplant extract was evaluated by three different methods: DPPH, ABTS, and FRAP (Figure 4). It is important to use more than one method for the uniform assessment of the antioxidant activity of a sample, as the different methods have different mechanisms of action. Moreover, the reagents used in the methods react differently with the wide range of phenolic compounds present in the samples. Thus, the differences in the chemical structures of phenolics and the complex chemistry of the reactions involved in the methods lead to variations in the assay results (Alagraftingm et al., 2021). In principle it is difficult to compare the obtained results of antioxidant activity with already published because of the different methods used and principally because of the different ways of expressing the results, and in this specific case the lack of data available for this bioresource. According to Figure 4, we can see that extracts made with $\mathrm{OH}$ had higher antioxidant activities than extracts made with conventional heating. This showed positive correlation between the amount of phenolics and proteins in the extracts and their antioxidant activity, fact confirmed also by Plazas et al. (2013). The highest antioxidant activities, regardless the method of extraction used, were registered for solvents with of 30,50, and $70 \%$ ethanol. The FRAP values of Rotonda's red eggplant extracts had higher values (up to 10-folds) than the ones published for six different cultivars of eggplants fruits (Orient Express, Orient Charm, Italian Neon, and Calliope Zebra Stripe, Blackbell and Millionaire) (Luthria, 2012). Also according to published data (Gürbüz et al., 2018) the antioxidant activity of eggplant ranges from 2,664 to $8,247 \mathrm{mmol}$ trolox/ $\mathrm{kg}$ of dry eggplant, results lower than the presented in this study. The demonstrated high antioxidant activity of extracts from Rotonda's Red eggplant is in accordance with the results published by Parisi et al. (2018).

Taking in consideration the results described, it was considered that the extract obtained using 50\% ethanol extracts made with $\mathrm{OH}$, had the best characteristics (higher phenolic compounds content and higher antioxidant activity) and it was used in the following characterization (antibacterial activity and cytotoxicity).

\section{Antibacterial Activity}

After analyses in terms of phenolic content and antioxidant activity of several extracts, $50 \%$ ethanol extracts made with $\mathrm{OH}$ were selected for the determination of MIC and MBC against four pathogens. The results obtained are displayed in Table 4.
TABLE 4 | Minimal inhibitory concentration (MIC) and minimal bactericidal concentrations (MBC) of extracts obtained from Red eggplant against $L$. monocytogenes, S. aureus, S. enterica ser. Enteritidis, and E. coli.

\begin{tabular}{llcc}
\hline Gram & Microorganism & $\begin{array}{c}\text { MIC } \\
(\mathbf{m g} / \mathbf{m L})\end{array}$ & $\begin{array}{c}\text { MBC } \\
\mathbf{( m g} / \mathbf{m L})\end{array}$ \\
\hline$(+)$ & S. aureus & $>20$ & $>20$ \\
$(+)$ & L. monocytogenes & 20 & $>20$ \\
$(-)$ & S. Enteritidis & 10 & $>20$ \\
$(-)$ & E. coli & 10 & $>20$ \\
\hline
\end{tabular}

Values are expressed as mean $(\mathrm{mg} / \mathrm{L}) \pm S D$. The MIC experiments were performed four times and the $M B C$ tests were carried in duplicate.

The MIC is defined as the lowest concentration of an antimicrobial agent that completely inhibits the growth of the organism in the microdilution wells as detected by the unaided eye (CLSI, 2012). In this study, Red eggplant extracts showed greater inhibitory activity, with MIC of $10 \mathrm{mg} / \mathrm{mL}$, against Gramnegative bacteria tested (Salmonella enterica subsp. enterica serovar Enteritidis and E. coli). Regardless, these extracts did not show activity against Gram-positive bacteria (L. monocytogenes and $S$. aureus). The extracts failed to kill the bacteria at the tested concentrations of 20 and $10 \mathrm{mg} / \mathrm{mL}$. Therefore, the MBC of these extracts were $>20 \mathrm{mg} / \mathrm{mL}$.

There are not many data in the literature on the antibacterial activity of eggplant by-products. Therefore, our results can give an indication of potential antibacterial activity against Gramnegative bacteria in foods produced with this vegetable.

Actually, consumers are more concerned about the relationship between diet and health, which has led the food industry to develop new foodstuff that not only provides the necessary nutrients but also promotes health through diet. It is well-known that the regular intake of food enriched with different bioactive compounds can prevent various disorders related to lifestyle such as obesity, cancer, diabetes, hypertension and cardiovascular diseases (Agregán et al., 2021). As above mentioned, Red eggplant is an excellent source of phytochemicals, highlighted by its high level of phenolic compounds with antioxidant activity and some antibacterial activity, so it can be used for preparing different functional foods with beneficial properties.

\section{Cytotoxicity}

Different concentrations of Red eggplant extracts were placed in contact with the cells and their ability to metabolize resazurin into resorufin was used as a measurement of cells metabolic activity. A decreased of resazurin conversion indicates impairment of cellular metabolism (Helm et al., 2017; FerreiraSantos et al., 2020a), being an indication of the extract toxicity. The cells were exposed to different concentrations of each extract for $24 \mathrm{~h}(0-2,000 \mu \mathrm{g} / \mathrm{mL})$ and results are shown in Figure 5.

The Red eggplant extracts revealed no toxicity for the tested cells (L929 and Caco-2) at the tested concentration ranges, demonstrating their consumption to be safe, reinforcing the use of red eggplant as food and in the preparation and fortification 


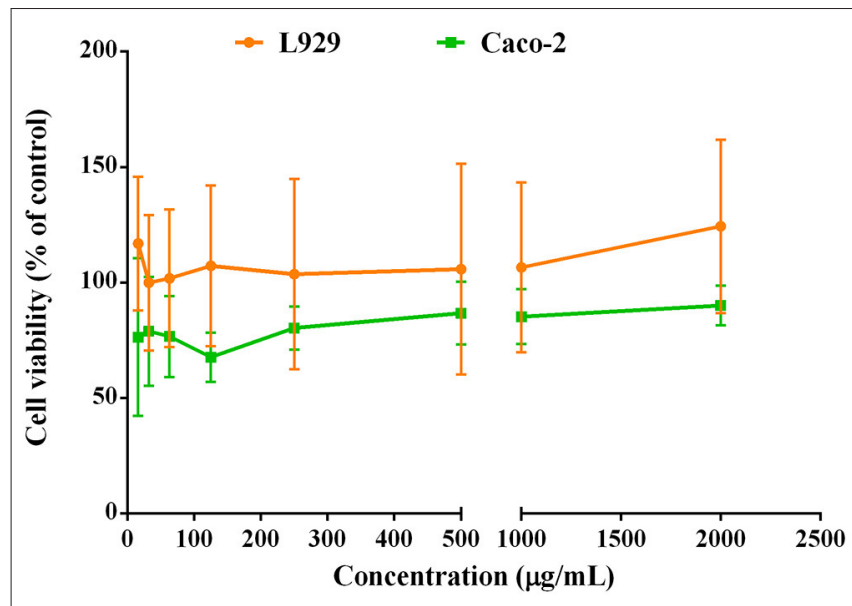

FIGURE 5 | Cell toxicity of ohmic heating ethanolic extract from Rotonda's Red eggplant, using normal skin fibroblast cells (L929) and colorectal adenocarcinoma cells (Caco-2).

of foods to produce functional foods, due to their high content into bioactive and functional compounds. Further, the extraction procedure did not induce toxicity to the extracts, being these also safe to be used as ingredients.

Kalebar et al. (2020) reported that the methanolic extract from Solanum macranthum fruit was found to possess significant antioxidant properties and specific cytotoxic effect toward breast cancer cells while posing no toxic effect on the normal cell line (L929), revealing its potential application as anticancer agent. Also, in our study the Red eggplant extract showed a slight reduction in the cell viability of Caco-2 cancer cells, comparatively to L929 cells.

Moreover, Parisi et al. (2018) concluded that red eggplant extracts obtained with $5 \%$ of hydrochloric acid in water, do not have a cytotoxic effect in pre-adipocyte cells (3T3-L1).

\section{CONCLUSIONS}

Results from the present study showed that Red eggplant from Rotonda (Italy) present an interesting nutritional value in terms of carbohydrates, fiber, proteins and bioactives, such as phenolics compounds.

Moreover, $\mathrm{OH}$-assisted extraction caused a significant increase in total phenolic compounds concentration in Red eggplant extracts with significant saves in energy consumption. The use of ethanol in combination with $\mathrm{OH}$ altered the

\section{REFERENCES}

Agregán, R., Munekata, P. E. S., Feng, X., Astray, G., Gullón, B., and Lorenzo, J. M. (2021). Recent advances in the extraction of polyphenols from eggplant and their application in foods. LWT 146:111381. doi: 10.1016/j.lwt.2021.111381

Alagraftingm, M. Z., Alhebsi, M. S. R., Ghnimi, S., and KamalEldin, A. (2021). Inability of total antioxidant activity assays to process selectivity, further boosting the extraction yield of phenolic compounds and proteins and increasing the antioxidant activities. The chromatographic analyses allowed the characterization of the phenolic compounds profile of the underexploited Red eggplant fruit, and the most representative compounds are ellagic acid, $p$-coumaricic acid and epicatechin, narginin, taxifolin and kaempferol. The extracts displayed antibacterial effects against foodborne bacteria. Furthermore, they had no toxicity to L929 and Caco-2 cells at the tested concentrations, which represents a positive clue regarding safety issues. Overall, the Red eggplant and its extracts can be used in the food and nutraceutical industry as potential sources of functional dietary ingredients. Though results in vitro and ex vivo results regarding extracts' bioactivity and toxicity are promising and no risk for the consumers is foreseen, further validation should be made in real food formulations.

\section{DATA AVAILABILITY STATEMENT}

The original contributions presented in the study are included in the article/Supplementary Material, further inquiries can be directed to the corresponding author/s.

\section{AUTHOR CONTRIBUTIONS}

PF-S, AD, and JT: conceptualization. PF-S, AD, BS, and ZG: data curation. PF-S, ZG, FD, and JT: formal analysis. JT and DG: funding acquisition and project administration. PF-S, AD, BS, and CB: investigation. PF-S, ZG, CB, and CR: methodology. PF-S, CB, CR, and JT: resources. PF-S and BS: software. CB, CR, and JT: supervision. PF-S, ZG, CB, CR, and JT: validation. PF-S and ZG: writing-original draft. PF-S, ZG, CB, CR, JT, and FD: writing-review and editing. All authors have read and agreed to the published version of the manuscript.

\section{FUNDING}

This research was funded by the Portuguese Foundation for Science and Technology (FCT) under the scope of the strategic funding of UIDB/04469/2020 unit and by program Marie Skłodowska-Curie grant (MSCA-RISE; FODIAC; 778388).

\section{SUPPLEMENTARY MATERIAL}

The Supplementary Material for this article can be found online at: https://www.frontiersin.org/articles/10.3389/fsufs. 2021.804004/full\#supplementary-material accurately assess the phenolic compounds of date palm fruit (Phoenix dactylifera L.). NFS J. 22, 32-40. doi: 10.1016/j.nfs.2021.0 1.001

Batista, A. P., Gouveia, L., Bandarra, N. M., Franco, J. M., and Raymundo, A. (2013). Comparison of microalgal biomass profiles as novel functional ingredient for food products. Algal Res. 2, 164-173. doi: 10.1016/j.algal.2013.01.004 
Bradford, M. M. (1976). A rapid and sensitive method for the quantitation of microgram quantities of protein utilizing the principle of protein-dye binding. Anal. Biochem. 72, 248-254. doi: 10.1016/0003-2697(76)90527-3

Busaranon, K., Suntornsuk, W., and Suntornsuk, L. (2006). Comparison of UV spectrophotometric method and high performance liquid chromatography for the analysis of flunarizine and its application for the dissolution test. J. Pharm. Biomed. Anal. 41, 158-164. doi: 10.1016/j.jpba.2005.11.008

CLSI (2012). Methods for Dilution Antimicrobial Susceptibility Tests for Bacteria That Grow Aerobically; Approved Standard - Ninth Edition. CLSI document M07-A9. Wayne, PA: Clinical and Laboratory Standards Institute.

Doganlar, S., Frary, A., Daunay, M. C., Lester, R. N., and Tanksley, S. D. (2002). Conservation of gene function in the Solanaceae as revealed by comparative mapping of domestication traits in eggplant. Genetics 161, 1713-1726. doi: 10.1093/genetics/161.4.1713

Ferreira-Santos, P., Genisheva, Z., Botelho, C., Santos, J., Ramos, C., Teixeira, J. A., et al. (2020a). Unravelling the biological potential of pinus pinaster bark extracts. Antioxidants 9:334. doi: 10.3390/antiox9040334

Ferreira-Santos, P., Genisheva, Z., Pereira, R. N., Teixeira, J. A., and Rocha, C. M. R. (2019). Moderate electric fields as a potential tool for sustainable recovery of phenolic compounds from Pinus pinaster bark. ACS Sustain. Chem. Eng. 7, 8816-8826. doi: 10.1021/acssuschemeng.9b00780

Ferreira-Santos, P., Ibarz, R., Fernandes, J.-M., Pinheiro, A. C., Botelho, C., Rocha, C. M. R., et al. (2021a). Encapsulated pine bark polyphenolic extract during gastrointestinal digestion: bioaccessibility, bioactivity and oxidative stress prevention. Foods 10:328. doi: 10.3390/foods10020328

Ferreira-Santos, P., Miranda, S. M., Belo, I., Spigno, G., Teixeira, J. A., and Rocha, C. M. R. (2021b). Sequential multi-stage extraction of biocompounds from Spirulina platensis: combined effect of ohmic heating and enzymatic treatment. Innov. Food Sci. Emerg. Technol. 71:102707. doi: 10.1016/j.ifset.2021.102707

Ferreira-Santos, P., Zanuso, E., Genisheva, Z., Rocha, C. M. R., and Teixeira, J. A. (2020b). Green and sustainable valorization of bioactive phenolic compounds from pinus by-products. Molecules 25:2931. doi: 10.3390/molecules 25122931

Food and Agriculture Organization of the United Nations (FAO). FAOSTAT. Available online at: http://www.fao.org/faostat/en/\#data/QC (accessed May 6, 2021).

Gavahian, M., Farahnaky, A., Farhoosh, R., Javidnia, K., and Shahidi, F. (2015). Extraction of essential oils from Mentha piperita using advanced techniques: microwave versus ohmic assisted hydrodistillation. Food Bioprod. Process. 94, 50-58. doi: 10.1016/j.fbp.2015.01.003

Graziani, G., Schiavo, S., Nicolai, M. A., Buono, S., Fogliano, V., Pinto, G., et al. (2013). Microalgae as human food: chemical and nutritional characteristics of the thermo-acidophilic microalga Galdieria sulphuraria. Food Funct. 4, 144-152. doi: 10.1039/C2FO30198A

Gürbüz, N., Uluişik, S., Frary, A., Frary, A., and Doganlar, S. (2018). Health benefits and bioactive compounds of eggplant. Food Chem. 268, 602-610. doi: 10.1016/j.foodchem.2018.06.093

Haliński, Ł. P., Samuels, J., and Stepnowski, P. (2017). Multivariate analysis as a key tool in chemotaxonomy of brinjal eggplant, African eggplants and wild related species. Phytochemistry 144, 87-97. doi: 10.1016/j.phytochem.2017. 09.001

Hanson, P. M., Yang, R. Y., Tsou, S. C. S., Ledesma, D., Engle, L., and Lee, T. C. (2006). Diversity in eggplant (Solanum melongena) for superoxide scavenging activity, total phenolics, and ascorbic acid. J. Food Compos. Anal. 19, 594-600. doi: 10.1016/j.jfca.2006.03.001

Hashemi, S. M. B., Nikmaram, N., Esteghlal, S., Mousavi Khaneghah, A., Niakousari, M., Barba, F. J., et al. (2017). Efficiency of ohmic assisted hydrodistillation for the extraction of essential oil from oregano (Origanum vulgare subsp. viride) spices. Innov. Food Sci. Emerg. Technol. 41, 172-178. doi: 10.1016/j.ifset.2017.03.003

Helm, K., Beyreis, M., Mayr, C., Ritter, M., Jakab, M., Kiesslich, T., et al. (2017). In vitro cell death discrimination and screening method by simple and cost-effective viability analysis. Cell. Physiol. Biochem. 41, 1011-1019. doi: $10.1159 / 000460910$

Jesus, M. S., Ballesteros, L. F., Pereira, R. N., Genisheva, Z., Carvalho, A. C., Pereira-Wilson, C., et al. (2020). Ohmic heating polyphenolic extracts from vine pruning residue with enhanced biological activity. Food Chem. 316:126298. doi: 10.1016/j.foodchem.2020.126298
Kacjan Maršic, N., Mikulič-Petkovšek, M., and Štampar, F. (2014). Grafting in fluences phenolic pro fi le and carpometric traits of fruits of greenhousegrown eggplant (Solanum melongena L.). J. Agric. Food Chem. 62, 10504-10514. doi: $10.1021 / \mathrm{j} f 503338 \mathrm{~m}$

Kalebar, V. U., Hoskeri, J. H., Hiremath, S. V., and Hiremath, M. B. (2020). In-vitro cytotoxic effects of Solanum macranthum fruit. Dunal extract with antioxidant potential. Clin. Phytoscience 6, 1-13. doi: 10.1186/s40816-020-0 0163-2

Loypimai, P., Moongngarm, A., Chottanom, P., and Moontree, T. (2015). Ohmic heating-assisted extraction of anthocyanins from black rice bran to prepare a natural food colourant. Innov. Food Sci. Emerg. Technol. 27, 102-110. doi: 10.1016/j.ifset.2014.12.009

Lu, D., Zhang, M., Wang, S., Cai, J., Zhou, X., and Zhu, C. (2010). Nutritional characterization and changes in quality of Salicornia bigelovii Torr. during storage. LWT Food Sci. Technol. 43, 519-524. doi: 10.1016/j.lwt.2009. 09.021

Luthria, D. L. (2012). A simplified UV spectral scan method for the estimation of phenolic acids and antioxidant capacity in eggplant pulp extracts. J. Funct. Foods 4, 238-242. doi: 10.1016/j.jff.2011.11.002

Masuko, T., Minami, A., Iwasaki, N., Majima, T., Nishimura, S. I., and Lee, Y. C. (2005). Carbohydrate analysis by a phenol-sulfuric acid method in microplate format. Anal. Biochem. 339, 69-72. doi: 10.1016/j.ab.2004. 12.001

Mauro, R. P., Agnello, M., Rizzo, V., Graziani, G., Fogliano, V., Leonardi, C., et al. (2020). Recovery of eggplant field waste as a source of phytochemicals. Sci. Hortic. 261:109023. doi: 10.1016/j.scienta.2019.1 09023

Meneses, N. G. T., Martins, S., Teixeira, J. A., and Mussatto, S. I. (2013). Influence of extraction solvents on the recovery of antioxidant phenolic compounds from brewer's spent grains. Sep. Purif. Technol. 108, 152-158. doi: 10.1016/j.seppur.2013.02.015

Nwanna, E. E., Ibukun, E. O., and Oboh, G. (2019). Nutritional content of selected species of tropical eggplant fruit (Solanum spp.) diet Attenuates hepatic inflammation in high-fat fed male Wistar rats induced with streptozotocin. Food Sci. Nutr. 7, 109-119. doi: 10.1002/fsn3.811

Parisi, O. I., Ruffo, M., Amone, F., Malivindi, R., Gorgoglione, D., De Biasio, F., et al. (2018). PDO Rotonda's red eggplant extract: in vitro determination of biological properties and minerals bioaccessibility. Curr. Nutr. Food Sci. 16, 65-74. doi: 10.2174/1573401314666180622110952

Pataro, G., Barca, G. M. J., Pereira, R. N., Vicente, A. A., Teixeira, J. A., and Ferrari, G. (2014). Quantification of metal release from stainless steel electrodes during conventional and pulsed ohmic heating. Innov. Food Sci. Emerg. Technol. 21, 66-73. doi: 10.1016/j.ifset.2013.11.009

Pereira, R. N., Rodrigues, R. M., Genisheva, Z., Oliveira, H., de Freitas, V., Teixeira, J. A., et al. (2016). Effects of ohmic heating on extraction of food-grade phytochemicals from colored potato. LWT - Food Sci. Technol. 74, 493-503. doi: 10.1016/j.lwt.2016.07.074

Plazas, M., López-Gresa, M. P., Vilanova, S., Torres, C., Hurtado, M., Gramazio, P., et al. (2013). Diversity and relationships in key traits for functional and apparent quality in a collection of eggplant: fruit phenolics content, antioxidant activity, polyphenol oxidase activity, and browning. J. Agric. Food Chem. 61, 8871-8879. doi: 10.1021/jf402429k

Raigón, M. D., Prohens, J., Muñoz-Falcón, J. E., and Nuez, F. (2008). Comparison of eggplant landraces and commercial varieties for fruit content of phenolics, minerals, dry matter and protein. J. Food Compos. Anal. 21, 370-376. doi: 10.1016/j.jfca.2008.03.006

Rocha, C. M. R., Genisheva, Z., Ferreira-Santos, P., Rodrigues, R., Vicente, A. A., Teixeira, J. A., et al. (2018). Electric field-based technologies for valorization of bioresources. Bioresour. Technol. 254, 325-339. doi: 10.1016/j.biortech.2018.01.068

Saberian, H., Hamidi-Esfahani, Z., Ahmadi Gavlighi, H., and Barzegar, M. (2017). Optimization of pectin extraction from orange juice waste assisted by ohmic heating. Chem. Eng. Process. Process Intensif. 117, 154-161. doi: $10.1016 /$ j.cep.2017.03.025

San José, R., Plazas, M., Sánchez-Mata, M. C., Cámara, M., and Prohens, J. (2016). Diversity in composition of scarlet (S. aethiopicum) and gboma (S. macrocarpon) eggplants and of interspecific hybrids between S. aethiopicum 
and common eggplant (S. melongena). J. Food Compos. Anal. 45, 130-140. doi: 10.1016/j.jfca.2015.10.009

Sastry, S. (2008). Ohmic heating and moderate electric field processing. Food Sci. Technol. Int. 14, 419-422. doi: 10.1177/1082013208098813

Singh, A. P., Luthria, D., Wilson, T., Vorsa, N., Singh, V., Banuelos, G. S., et al. (2009). Polyphenols content and antioxidant capacity of eggplant pulp. Food Chem. 114, 955-961. doi: 10.1016/j.foodchem.2008.10.048

Sluiter, A., Ruiz, A., Scarlata, C., Sluiter, J., and Templeton, D. (2008). Determination of Extractives in Biomass: Laboratory Analytical Procedure (LAP). Golden, CO: National Renewable Energy Laboratory.

Sunceri, F., Polignano, G., Alba, V., Lotti, C., Bisignano, V., Mennella, G., et al. (2010). Genetic diversity and characterization of African eggplant germplasm collection. Afr. J. Plant Sci. 4, 231-241. doi: 10.5897/AJPS.9000128

Tibbetts, S. M., Milley, J. E., and Lall, S. P. (2015). Chemical composition and nutritional properties of freshwater and marine microalgal biomass cultured in photobioreactors. J. Appl. Phycol. 27, 1109-1119. doi: 10.1007/s10811-014-0428-x

Zaro, M. J., Chaves, A. R., Vicente, A. R., and Concellón, A. (2014). Distribution, stability and fate of phenolic compounds in white and purple eggplants (Solanum melongena L.). Postharvest Biol. Technol. 92, 70-78. doi: 10.1016/j.postharvbio.2014.01.016
Conflict of Interest: FD was employed by the company Osun Solutions S.r.l, and $\mathrm{AD}$ and DG by EVRA S.r.l.

The remaining authors declare that the research was conducted in the absence of any commercial or financial relationships that could be construed as a potential conflict of interest.

Publisher's Note: All claims expressed in this article are solely those of the authors and do not necessarily represent those of their affiliated organizations, or those of the publisher, the editors and the reviewers. Any product that may be evaluated in this article, or claim that may be made by its manufacturer, is not guaranteed or endorsed by the publisher.

Copyright () 2021 Ferreira-Santos, Duca, Genisheva, Silva, De Biasio, Botelho, Rocha, Gorgoglione and Teixeira. This is an open-access article distributed under the terms of the Creative Commons Attribution License (CC BY). The use, distribution or reproduction in other forums is permitted, provided the original author $(s)$ and the copyright owner(s) are credited and that the original publication in this journal is cited, in accordance with accepted academic practice. No use, distribution or reproduction is permitted which does not comply with these terms. 